\title{
Music in Early Childhood Education: An Instrument for Preserving the 'Igbo' Musical Culture in Nigeria
}

\author{
Esimone, Chinyere Celestina (Ph.D.) \\ Department of Music. Nnamdi Azikiwe University, Awka, \\ Anambra State, Nigeria \\ admireesomchi@yahoo.com \\ Umezinwa, Emmanuel C. (Ph.D.) \\ Department of Music. Nnamdi Azikiwe University, Awka, \\ Anambra State, Nigeria \\ emma882000@yahoo.com
}

\section{Doi:10.5901/jesr.2013.v3n7p514}

\begin{abstract}
The world is changing fast, so is all that are therein; ranging from people, fashion and even culture. And if cultures actually change as civilisation and people are demanding, then the one single means of knowing a people will be lost. Truth be told, every nation has a culture they can not do away with irrespective of whatever, hence the importance of preserving that culture can never be overemphasised. Nigeria as a nation has diverse ethnic groups and tribes with different languages and cultures. Igbo tribe is one of the ethnic groups. Igbo tribe is rich with very relevant cultures which are embedded in its music, this musical culture need be preserved; and one easiest way through which this can be done is through its introduction in the early childhood education. Hence, this paper seeks to reveal the ability of music to preserve Igbo musical culture through early childhood education.
\end{abstract}

\section{Introduction}

Music is embedded with a strong power to transform, influence and affect the life of people all over the world irrespective of their position, colour, race or gender. It unarguably enjoys the place of the most influential form of art; hence it is the universal language of the soul. A language understood and appreciated by all beginning from the cradle to the grave. Many scholars have given different definitions to music. Blacking (1973) says it's a humanly organised sound (p.57). Elliot (1995) believed "it is a diverse human practice of constructing aural temporal patterns for the primary values of enjoyment, self growth and self knowledge" (p.128). Walker (1998) says "it is a living analogue of human knowing, feeling, sensibility, emotions, intellectual modus operandi and all other life-giving forces which affect human behaviour and knowing" (p. 57). And Agu (2006) sees it as "an aesthetic art of combining or putting together sounds that are pleasant to the ear.

Music is a gift from God through which we strive to express our joy for the things that are real to us and our longings for the things that might be. The power of music can not be overemphasised hence Abeles, Hoffer and Klotmann (1984) asserts:

Music directly emanates (shows) the passion or states of the soul - gentleness, anger, courage, temperance and their opposites and other qualities; hence when one listens to music that imitates a certain passion, he becomes imbued with the same passion, and if over a ling time, he habitually listens to the kind of music that arouses ignoble passions, his whole character will be shaped to an ignoble form (p.4)

This means music has so much power to influence and achieve its intended lyrics by the performer. Hence if we wish to produce patriotism in an individual, we sing or perform patriotic and stimulating music, if we wish to produce calmness and tranquillity in therapy, we perform music that is calm and tranquil. And if we wish to preserve our musical cultural heritage, music becomes an asset for it. 


\section{Culture}

Every nation is an embodiment of culture. And culture is seen as a people's way of life. It describes the several influences on a group of people or a community which had to do with their knowledge, character and learned behaviour. The Oxford Advanced Learner's Dictionary (2000) explains culture as "the customs and beliefs, art, way of life and social organisation of a particular country or group" (p. 284). In order words every society and nation has a culture which they are known for and which defines them. For example, there is Western culture, Eastern culture, Middle Eastern culture, African culture and so on. Each of these cultures is defined by the values, traditions, social habits, behaviours, language, dress codes, belief system; food and even music that distinguishes them form other nations. And this cultural knowledge is no doubt passed on from generation to generation, and hence it is referred to as the cultural heritage of that people. This cultural heritage which indirectly signifies the flag of a people needs be preserved if that people are to be remembered and not be forgotten.

Nigeria as a nation is an embodiment of ethnic groups and tribes, and each of these groups and tribes are very rich in culture. The Igbo tribe which is one of the three major ethnic groups in Nigeria are, according to Okafor (2005),

An achievement oriented people, egalitarian and hardworking, serious minded and fiercely competitive people; majority of them are professionals in various fields of life, and not many of them are farmers ( $p .45)$.

However, irrespective of what their professions are, one thing binds them together; their music. The Igbo tribe is very rich in culture. This culture as will be revealed in this paper is seen in their music which portrays their way of life in terms of their attitudes towards 'respect for elders, dress codes, names, acceptable attitudes within and outside their home environment, language and so on, is observed to be fast disappearing. If nothing is done in the next few years to come, the lgbo tribe itself will no longer be remembered or recognised outside its environment. Hence this paper is set out to proffer a preservative method through which this mayhem could be avoided.

Obviously, the nation Nigeria was colonised, and with the colonisation came the transmission of the Western culture in terms of language (Nigeria has a lingua franca of English, thanks to the British); dressings and education which no doubt had helped bring about civilisation. Yet, the tribal language, dress code, and way of life, through which a people are known, irrespective of whatever influence, should be adhered to and preserved so long as they are good. And music of a people especially the lgbo tribe, is so important that its preservation should be a concern. Hence, one important and fastest way this could be done is through music in early childhood education. The Igbo music preservation is so important because through it, other intrinsic cultures are preserved since music communicates those cultures. To this, Okafor (2005) affirms:

The whole point about music in Igbo culture is that it is integral with life and closely related with the other art forms. Under these circumstances music plays a double role as a medium of cultural transmission and as music itself. It is a life long as well as comprehensive activity. Every Igbo person is expected to make music or perform at a dance at certain point in life. It is an activity in which one participates in childhood or in age. All life rites have musical implications and involvement so that at any point in time, somewhere, somebody is making music or dancing in lgbo land (p.27).

The above shows music is integral to every day life of the lgbo tribe and it's embedded in the culture. Echezona (1963), in Okafor (2005), concurring to the statement above asserts:

To every lgbo person, life has a melodic and rhythmic orientation, and again... no event happens that is not associated with music. The Igbos has an ardent personal feeling for it (p. 12).

Okafor (2005) supporting the statement above also noted: the Igbo cannot do without music and one of the most important attributes of Igbo music is that it is not only to listen to, but also to learn from (p. 27). Meaning, its music transmits the way of life of the Igbos (culture). Hence, the early childhood becomes a very important stage through which this preservation could be achieved, because of the position a child occupies in the culture of the lgbo tribe. Okafor (2005) in affirming this says:

The Igbo child is a product of nature and nurture. A child comes into the world enclosed with some natural traits. The child is influenced by the prevalent social habits of his time and place. Like culture, the child is largely characterised by his environment, and is therefore, attuned in the musical processes and products of his community (p. 45). 
Okafor further affirms:

Igbo names are not mere tags of identity or appellations but very deep expressions of attitudes, sentiments, aspirations and straightforward commentaries on life's experiences. Therefore most Igbo names cannot be fully appreciated without adequate knowledge of the Igbo worldview. If you want to know how life has treated an Igbo man, a good place to look is the names his children bear. His hopes, his fears, his joys and sorrows; his grievances against his fellows, or complaints about the way he has been used by fortune; even straight historical records are all there (p. 46).

Okafor (2005), in his affirmations of the centrality and importance of the Igbo child further noted:

In Igbo land, children are the pride of their parents. Consequently, great affection abounds between them, especially between mothers and their sons. A man with many children is regarded as rich and blessed. Hence childbirth is regarded as a blessing and an honour from God. And that is why most traditional Igbo families do not resort to either abortion or artificial family planning methods. This also explains why some poor couples have large families, believing that God will provide for the sustainance of these "His gifts" - children. This high premium placed on the child partly accounts for the high birth rate among the Igbo, and why polygamy is very common. They believe also that wealth cannot buy children (p. 47).

Children actually occupy a central place in the culture of the Igbo tribe. This made it very imperative that the best way through which the Igbo music could be preserved is through the early childhood education. Hence at this stage the children are still very tender and sharp to grasp whatever they are taught.

\section{Music in early childhood education}

Early childhood is seen as the age before normal schooling, usually from one (1) to five (5) years of age in most nations as well as in Nigeria. It is when the brain develops most rapidly, almost to its fullest. It is also when talking, self-esteem, vision of the world and moral foundations are established in a child. It is a period of rapid change and development and the most critical period in a child's musical growth, and has been identified in literature as the 'music babbles' stage (Moog and Gordon in Levinowitz, 1998. internet source). It is also identified as "the period of 'developmental music aptitude' in children through which their musical acumen is enhanced (Gordon in Levinowitz, 1998). Early childhood education is "the time when children learn about their world primarily through the magical process of play" (Levinowitz 1998). Hence Education is defined by Akumah (2004) as:

The process of development which consists of the passage of a human being from infancy to maturity, the process whereby he gradually adapts himself in various ways to his physical, social and spiritual environment (p. 203).

Walker (1998), on the other hand defined it as the:

Quest to gain understanding or what it means to be human in all its illogicality, its unpredictability, its irrationality and in all its uniquely varied cultural ways of doing and thinking (p. 32)

Early childhood education can therefore be referred to as a system through which children are made to acquire knowledge which will stir up the spirit of creativity, acquisition of skills and enquiry in them, and at the same time understand who they are and what is expected of them. In order words, it is a means through which the system of life through which they are expected to live is inculcated in them.

However, anyone who had known children and work with them knows they love music, and can engage in musical activities on many levels. It is a very natural and important part of their lives. Researches abound on how children are tuned to the nuances of music. They turn everything around them into music, and the easiest language they understand even from cradle is music. In Nigeria and especially in Igbo tribe, music occupies a very central and sensitive place in everything from cradle to grave of the people. Hence a little child in Nigeria responds to the language of music naturally. To this Nnamani (2004) asserts:

The average Nigeria child begins to respond to music right from the cradle. He starts early to acquire some experiences in life through listening to lullabies, cradle songs, other songs or experiences of rhythmic activities he acquires as he is on his mothers back, or clap rhythms in game songs and other songs. As early as six months of age, some children start to respond to music by moving to drumming. With all these musical experiences around a child at various developmental stages, the child naturally absorbs the musical sounds and patterns already formed at pre-school age (p. 97). 
In supporting the statement above, Okafor (2005) noted:

\begin{abstract}
Three months after birth, the baby is again introduced to the society when his mother begins to tie him to her back while going to public places like the market and streams in pursuit of normal chores. The child is thus his mother's companion in her daily activities like when she washes clothes in the stream..., or dances with her peer group or classificatory fellow wives. In a practical way, this is the baby's introduction to the music of its culture; through rhythmic body movements and vocal effort (p. 54-55).
\end{abstract}

All the above shows children, especially Igbo children are tuned to the nuances of music, which before now, comes from their mother, who spends most of her time with the children from the cradle to the age of pre-primary schooling. But now, because of acculturation, civilisation and influences from the western world, such knowledge is no longer the case. This because mothers, who are the primary children caretakers no longer, seat at home to take care of the children; they now spend most of their time in the offices like the men, from morning till evening doing office jobs, while the children are left with nannies who are after their salary rather than the upkeep of the children. As a result of this, children no longer have the opportunity of listening to lullabies and cradle songs that are rooted in the culture of the lgbo tribe. Such circumstances no doubt, is gradually leading to loss of those vital cultures on which the lgbo tribe is leaned on. For example, the Igbo tribe are known to greet their elders, dress to cover up their nakedness, showcase their traditional wears, bear and answer lgbo names, speak their tribal language and never be ashamed of it irrespective of where they are or who they are with. But this trend is no longer the case today; the opposite is rather the case. The younger generation now expects the elder to greet and pay homage to them; they seem to feel ashamed of themselves speaking their tribal language before people even among themselves. The pride of their names is being replaced with English names.

Besides, the traditional dressing which showcases the lgbo personality is now replaced with other forms of dressing and those who are still upholding those principles seem to look off and old fashioned in the eyes of the younger generation. The Igbo music, which is the bedrock of these other cultures, is now being replaced by the westerns' as well as other tribes' music. This no doubt is as a result of acculturation and absolute abandonment of the Igbo culture to a borrowed one. This situation has led to the pursuit for solution to help preserve the culture. And one important way is this could be achieved is through music in early childhood education.

Pre-schools are found in every nuke and cranny in Igbo tribe, and every child in Igbo land is given the opportunity to attend any of such kindergarten or pre-schools depending on the financial status of the family. (the Igbo's value education, whether Western or traditional). And irrespective of the financial ability of the family, these children are taught and they learn. It is obvious from researches that have been done that the children learn all the subjects such as English language, mathematics, social studies, Igbo language and so on, and the easiest way these subjects are taught is through music. And if this is the case, then the Igbo music which is embedded in the Igbo culture, which the mothers no longer have time to pass on to their children can now be done through the teachers in the kindergarten schools who also have their root from the lgbo tribe.

So many lgbo songs abound that are embedded in Igbo culture which communicates respect for elders, dress codes, encouragement to work hard and so on abound. Two of these songs are expressed here. One is song advising the child to respect both his parents and elders. The other one shows the punishment a disobedient child takes when he disobeys and a song for encouragement to work hard. The first song teaches, advices and encourages the child to be obedient, the second song serves as a deterrent to breaking the law, since it reveals the punishment that will be meted to the offender and the third, encourages diligence.

The following are the songs (music).

Cradle song for respect to elders titled: Kelee Onye Muru Gi (Greet Your Parents).

Kelee Onye Muru Gi Greet your parents

Kelee onye toro gi

Greet your elder

Nne gi gwa gi nuru

Hear (obey) the instructions of your mother

Nna gi gwa gi nuru

Tupu onye ozo

Hear (obey) your fathers instructions before

Ma gba mgbo ruwere

onye toro gi isi. (Okafor 2005)

heeding to those of another's

And persevere to respect your elders

When this music is sang or performed to the children, it instils in them the consciousness of respect and obedience to both their parents and the elders. One hardly sees a child who is disrespectful either within the home or outside the home environment. When children are seen disrespecting their parents or elders as it is these days, the 
statements that are often made is usually, this child is not raised at home, or, that the child lacks home training or, the family didn't really give birth to them in Igbo land. This is so because, such circumstances shows where that child is raised, whether at in Igbo land or outside.

The music above is followed up by another song which serves as a deterrent to children who would have wanted to take the wrong part. And it is performed thus:

\section{Tufuo nu nwa melu alu. Throw away the childthat has desecrated the land Eru echi a muta ozo tomorrow we get a new one. (Okafor, 2005).}

This music helps in instilling discipline in children and helps them to conform to the cultures that they have grown up to see, being practiced. It was proven to have served as a good deterrent instead of the cane. This is because, no child will want to be thrown away or deny the kind of super affection he or she is getting from parents, siblings, relatives and friends. Hence, they wilfully conform to the dictates of the culture.

The following is music to work hard and never get distracted because a labourer will always be rewarded. In order words, it is music for encouragement. It is performed thus:

$\begin{array}{ll}\text { Na lu n'olu, anyi g'enwe nmeri } & \text { Continue to labour, we'll be rewarded } \\ \text { Na lu n'olu, anyi g'enwe nmeri. } & \text { Continue to labour, we'll be rewarded } \\ \text { Onye olu nwere ugwu olu, } & \text { A labourer has a reward, } \\ \text { Anyi g'enwe nmeri } & \text { we'll be rewarded } \\ \text { Jisike n'olu, } & \text { Be strong in your duty, } \\ \text { anyi g'enwe nmeri. } & \text { We'll be rewarded. }\end{array}$

This music, whether it is performed to a child or an adult, has the power to encourage the hearer to actually work hard, because there is a reward that must come. This reward can be in the form of a gift, applause, money or whatever. This is one of the songs that made the Igbo people very hard working people. Every where an average Igbo man or woman is seen, he or she is an epitome of hard work, and they have their reward to show for it. This reward is seen in their wealth shown with many houses they own, many employees they have, many wives they marry and are responsible for. It is an abomination to see an Igbo man begging, because they are not associated with laziness. These reasons and many more are the reasons why the lgbo music culture is vey vital and must be preserved; and that through its introduction in the kindergarten for the new generation to learn, so as to get acculturated with the system.

There are other music that teaches other habits such as the way to dress, when to sleep, when to go out and play, what to do in the face of trouble and so on as well as music for praise when the child does what he or she is expected to do. All these are embedded in the music of the Igbo which made the Igbo music very sacred to the Igbo tribe.

In summary, this paper has showed that cultures reveal people, who they are and where they are from. When cultures are lost, it is obvious that the root of people have been lost. This paper has also proved that most of the lgbo cultures is embedded in their music. It has also shown the reason why their music should be preserved and that through the early childhood education.

\section{References}

Abeles, F. H., Hoffer, C. \& Klotman, R. (1984). Foundations of Music Education. New York: Schimer .

Agu, D. C. C. (2006). The Nigerian Policy on Education: Its impact on music education programme and delivery in Nigeria. Awka Journal of research in music and the arts (AJRMA). 3: 1-8.

Akumah, E. (2004). Concepts of functional education (pp.200-216). In R.C. Okafor and L. N. Emeka (Eds), Nigeria peoples and culture. Enugu: New Generations

Blacking, J. (1973). How Musical is Man? London: Faber \& Faber.

Elliot, D. J. (1995). Music matters: a new philosophy of music education. New York: Oxford Uninversity Press.

Levinowitz, L.M. (1998). The importance of music in early childhood education. In the General music today. Music educators national conference 1998. Available at http://www.musictogether.com/Import. [Accessed 3rd July 2013]

Nnamani, S. N. (2004). The role of music in nursery education in Nigeria. Awka Journal of Research in Music and the Arts (AJRMA) 2 , 93-101

Okafor, R. C. (2005). Music in Nigerian Society. Enugu: New Generation.

Oxford Learners Advanced Dictionary (2000). 6th Edition. A. S. Hornby (ed). New York: Oxford University Press.

Walker, R. (1998). In music education, a hundred flowers blossom and a hundred Schools of thought contend. Is this a problem? International Journal of Music Education (IJME). 1, 32 - 34 